\title{
The impact of cultural diversity on the innovation performance of MNC subsidiaries in strategic alliances
}

Article

Accepted Version

Creative Commons: Attribution-Noncommercial-No Derivative Works 4.0

Elia, S., Messeni Petruzzelli, A. and Piscitello, L. (2019) The impact of cultural diversity on the innovation performance of MNC subsidiaries in strategic alliances. Journal of Business Research, 98. pp. 204-213. ISSN 0148-2963 doi: https://doi.org/10.1016/j.jbusres.2019.01.062 Available at https://centaur.reading.ac.uk/81828/

It is advisable to refer to the publisher's version if you intend to cite from the work. See Guidance on citing.

To link to this article DOI: http://dx.doi.org/10.1016/j.jbusres.2019.01.062

Publisher: Elsevier

All outputs in CentAUR are protected by Intellectual Property Rights law, including copyright law. Copyright and IPR is retained by the creators or other copyright holders. Terms and conditions for use of this material are defined in the End User Agreement.

www.reading.ac.uk/centaur 
Central Archive at the University of Reading

Reading's research outputs online 


\title{
THE IMPACT OF CULTURAL DIVERSITY ON THE INNOVATION PERFORMANCE OF MNC SUBSIDIARIES IN STRATEGIC ALLIANCES
}

\author{
Stefano Elia, DIG-Politecnico di Milano \\ Antonio Messeni Petruzzelli, Politecnico di Bari \\ Lucia Piscitello, University of Reading \& Politecnico di Milano
}

\begin{abstract}
The strategy literature has widely acknowledged the negative impact of cultural diversity between the partners of an alliance on their innovation performance. We argue that innovation is even more challenging in alliances involving subsidiaries of multinational companies (MNCs), as they embody a dual background that encompasses the cultures of their host country and their home country. We also propose that the effect of cultural diversity is contingent on the specific content of the alliance, and that it is positive in explorative alliances and negative in exploitative alliances. Our findings, which are obtained from an analysis of 161 strategic alliances established by $31 \mathrm{MNC}$ subsidiaries in the biotech industry during the period 1987 to 2010, confirm that subsidiaries are generally less innovative in alliances involving partners from other cultures. However, the impact of such cultural diversity becomes positive when those alliances focus on exploration activities, as the challenges of cultural diversity are offset by the benefits of exposure to novel cognitive schemes.
\end{abstract}

Keywords: cultural diversity, strategic alliance, MNC subsidiary, innovation performance, exploration, exploitation 


\section{Introduction}

The extant literature on alliances demonstrates that partners' characteristics and their diversity play crucial roles in alliance success (e.g., Capaldo \& Messeni Petruzzelli, 2014; Hoffman \& Schlosser, 2001; Reuer \& Lahiri, 2014). The selection of suitable partners is crucial, as it ensures access to complementary knowledge and resources (Kogut \& Zander, 1992). This is particularly true in high-technology industries in which firms face competition in terms of time and costs, rapid technological development, short product life cycles, and increasing capital expenditures (e.g., Rothaermel \& Deeds, 2004).

In recent decades, cross-border alliances have assumed a prominent strategic role on the global stage (Berry, 2014). Previous studies have revealed that alliance-related processes and outcomes are significantly influenced by the cultural differences between the partners' home countries (Steensma et al., 2000). These differences affect how firms interact and learn from each other, as well as their exchange of knowledge, resources, and competencies. Thus, unlike domestic alliances, cross-border collaborations suffer from "double layered acculturation" (Barkema et al., 1996, p. 154) that "may inhibit the informal chemistry that is essential for coordination and ongoing conflict resolution in alliances" (Lavie \& Miller, 2008, p. 626).

In this context, we claim that the challenge is further exacerbated when strategic alliances are established by foreign subsidiaries of multinational companies (MNCs). In such cases, cultural diversity assumes multifaceted dimensions, as MNC subsidiaries are characterized by a dual-culture background - they embody both the culture of the host country in which they are located and the culture of their parent's home country (Smale et al., 2015). This implies that the challenge is one of "multilayered acculturation": indeed, in order to fully understand a subsidiary's ability to leverage a strategic alliance, its cultural fit with its partner should be assessed in terms of both the host-and home-country dimensions. While the 
host country dimension is associated with the extent to which the subsidiary is able to learn from the partner, the home country dimension refers to the extent to which the subsidiary is able to recombine the knowledge provided by the partner with the internal capabilities of the parent company (e.g., Di Minin \& Bianchi, 2011; Monteiro \& Birkinshaw, 2017; Zaheer \& Hernandez, 2011).

In addition, we claim that the impact of cultural diversity depends on the content of the alliance. More specifically, when an alliance aims to explore and develop new technological paths rather to exploit those already in existence (Rothaermel \& Deeds, 2004), cultural diversity may result in benefits that outweigh the costs, thereby reducing its harmful influence on subsidiary innovativeness (West, 2002). In particular, the explorative nature of an alliance reduces the challenges associated with diversity in interactions with alliance partners, and positively affect the subsidiary's innovation activities by leveraging those aspects of diversity that are related to variety and creativity (Stahl et al., 2010).

In order to test our conceptual framework, we develop an empirical analysis that covers 161 strategic alliances established by $31 \mathrm{MNC}$ subsidiaries in the biotech industry in the period 1987 to 2010 . The focal timeframe encompasses a key period in the evolution of the biotechnology industry, especially with regard to technological developments and internationalization. As such, it offers an opportunity to capture and analyze the dynamics under investigation. Our findings confirm that MNC subsidiaries tend to be less innovative when their alliance partners are culturally distant from both their host and home countries. We also find that alliances of an explorative nature exert a moderating effect, which reduces the negative influence of cultural diversity on the MNC subsidiary's ability to learn from its partners and acquire the knowledge needed to innovate.

This paper focuses on the impact of cultural diversity on the innovation performance of cross-border alliances, a topic for which previous studies have provided mixed evidence 
(e.g., Bjorkman et al., 2007; Milliken et al., 2003). We offer several theoretical and empirical insights that help clarify the reasons for the contradictory results in the extant literature and, hence, point to more clear-cut managerial implications. First, we add to the ongoing debate in the international business and management literature (Shenkar, 2012) on the role of cultural diversity in cross-border alliances. We do so by acknowledging that MNC subsidiaries are characterized by a dual-culture background that influences how they source and recombine knowledge, and by showing that these activities are contingent on the nature of alliance. Second, by adding the role of the cultural context to the resource dependence approach (Steensma et al., 2000), we contribute to a better understanding of the extent to which a firm is effectively able to leverage external resources when engaging in cross-border strategic alliances. In this regard, we shed new light on the determinants of MNC subsidiaries' innovative performance (e.g., Cantwell \& Piscitello, 2014; Phene \& Almeida, 2008) by showing how subsidiaries leverage alliances to generate new technological solutions, thereby contributing to research on both international business and innovation. Taken together, these contributions enable us to warn MNCs' decision makers about the need to ensure a proper cultural mix when engaging in a strategic alliance by avoiding overly distant partners in exploitative alliances and by reconsidering the value of diversity in explorative alliances.

The paper is structured as follows. In the next section, we illustrate the theoretical foundations of our research and develop our hypotheses. Thereafter, we present our methodology and data, as well as the variables we employ to test the hypotheses. We then discuss the main findings before highlighting their implications for theory and practice. In addition, we discuss several possible directions for future research.

\section{Conceptual framework and hypotheses}

\subsection{Cultural diversity in cross-border alliances involving MNC subsidiaries}


According to resource dependence theory (RDT) (Pfeffer \& Salancik, 1978), strategic alliances provide access to external resources that reduce technological uncertainty and the costs associated with innovation. We extend the RDT by taking the role of cultural distance into account when considering cross-border alliances (Steensma et al., 2000). More specifically, we disentangle the multilayered acculturation challenge that arises when the unit of analysis is an MNC subsidiary.

Extant work on strategic alliances has largely emphasized the negative role of cultural differences between the focal firm and its partners (Shenkar, 2012), as those differences create barriers to efficient resource exchange. Cultural diversity is expected to give rise to coordination and negotiation costs, which make it more difficult to transfer knowledge (Bell \& Zaheer, 2007). In fact, cultural diversity constitutes a friction that not only generates "heat and resistance" (Shenkar, 2012, p. 15) but also hinders trust and embeddedness (Sirmon \& Lane, 2004). The rationale is that differences in language, communication patterns, opinions, attitudes, and beliefs increase the costs of acquiring and leveraging knowledge across organizational boundaries (Stahl et al., 2010). Cultural environments influence how allied organizations perceive threats and opportunities, as well as the cognitive schemes and problem-solving approaches they adopt, which in turn affect their innovation outcomes (Barkema \& Vermuelen, 1997; Bartholomew, 1997).

Difficulties associated with cultural diversity tend to be particularly relevant in international $R \& D$ alliances, which require more resources for communication, the design of compatible work routines, and the development of common managerial approaches (Olk, 1997). As soon as such an alliance is launched, the partners' cultures have the potential to significantly affect all aspects of the collaboration, including the knowledge-sharing and knowledge-acquisition processes (Tiemessen et al., 1997). This view is shared by Lyles and Salk (1996), who report that conflicts and cultural misunderstandings rooted in cultural 
differences can restrict flows of information and learning. Similarly, Mowery, Oxley, and Silverman (1996) point to cultural differences between partners as a key obstacle to interfirm knowledge transfers.

We expand this debate by proposing that this negative effect is likely to be amplified for an MNC's foreign subsidiaries, as they embody both the culture of the host country in which they are located and the culture of the country in which their parent is located (Smale et al., 2015). This fosters a multiple acculturation challenge that increases the negative influence of cultural diversity. More specifically, we believe that there are two facets of cultural diversity in such cases - diversity related to the host- and the home-country components that are embedded in the subsidiary.

\subsection{The impact of multicultural diversity on innovation in MNC subsidiaries}

Since the mid-1980s, researchers have increasingly focused on the importance of internal and external networks for innovation in MNCs. In this regard, there has been a growing awareness that MNCs use their transnational networks to sustain and enhance their competitive advantages (Berry, 2014). This view highlights the key role played by foreign subsidiaries as both providers and receivers of knowledge in the MNC (Bjorkman et al., 2007) and explains the motivation behind investigations of the antecedents of subsidiaries' innovative performance (Phene \& Almeida, 2008). MNC subsidiaries interact with internal networks of different actors, thereby engaging in cross-border knowledge exchange with their parent and their sister subsidiaries (Cantwell \& Piscitello, 2014; Zaheer \& Hernandez, 2011). In terms of external networks, strategic alliances have been shown to play a fundamental role (Contractor \& Lorange, 2002), as they enable subsidiaries to access knowledge and other critical resources beyond their boundaries, which they can use to nurture their innovative capabilities (Anderson, Forsgren, \& Holm, 2002; Gulati, 1999). 
On the one hand, the sourcing of external knowledge by subsidiaries requires strict interactions with alliance partners, which are likely to be threatened by the host-country cultural dimension of the subsidiary. Diversity between alliance partners is expected to have a direct influence on the ways in which the subsidiary recognizes, values, and assimilates the partner's knowledge (Cohen \& Levinthal, 1990; Monteiro \& Birkinshaw, 2017; Palich \& Gomez-Mejia, 1999;). Different languages, vocabularies, coding schemes, communication patterns, and styles significantly affect a subsidiary's “in decoding and encoding the knowledge emanating from a different [cultural] domain" (Zaheer \& Hernandez, 2011, p. 113). In other words, cultural distance is likely to reduce the connection and the relatedness between the partners, thus weakening the effectiveness of knowledge acquisition (i.e., the extent to which partners are able to comprehend and retain each other's knowledge), which is required to foster the generation of new knowledge within the alliance (Inkpen, 2000).

Furthermore, as cultural diversity increases, collaborative relationships between the two parties may become more asymmetrical in terms of information transfer and information sharing (Zeng et al., 2013). Diversity tends to reduce trust between partners, as it hampers open and prompt communication (Das \& Teng, 1998), and it may cause a mismatch with the subsidiary's dominant logics (Prahalad \& Bettis, 1986). In addition, a lack of trust between partners is likely to minimize the interactions and knowledge exchange between them, consequently reducing the accessibility of knowledge (i.e., the extent to which partners are able to access each other's knowledge), which is required to trigger the generation of new knowledge within an alliance (Inkpen, 2000).

Therefore, we argue that diversity between the partner's culture and the host-country culture of the subsidiary may hamper the latter's innovation performance by hindering the sourcing of the partner's knowledge. Accordingly, our first hypothesis states the following: 
Hypothesis 1. Cultural diversity between the allied partner and the MNC subsidiary's

host country has a negative impact on the subsidiary's innovation performance.

On the other hand, new knowledge creation by the subsidiary also relies on the internal recombination of sourced knowledge with the existing knowledge base. The innovative potential of the recombinant process depends on the firm's ability to efficiently employ sourced knowledge within its own innovation process (Galunic \& Rodan, 1998), avoid the risk of incorrect applications (Messeni Petruzzelli \& Savino, 2014), and establish novel connections among knowledge resources (Schilling \& Green, 2011). In this regard, Li \& Vanhaverbeke (2009) demonstrate that the selection of partners with similar cultural backgrounds sustains the development of pioneering innovations, as it enhances the effectiveness of the recombinant process. In line with this reasoning, Schmidt \& Sofka (2009) show that cultural barriers reduce the effectiveness of leveraging acquired knowledge, thereby increasing the risk that it will be used in inappropriate contexts.

In MNCs, this capability is likely to be imprinted on subsidiaries by the MNC parent and, accordingly, inherently related to the home-country cultural dimension, which typifies the interpretative approaches adopted by the subsidiary (Monteiro \& Birkinshaw, 2016). The parent company influences how the subsidiary interprets external knowledge, identifies connections with the MNC's knowledge base, and develops innovations (Di Minin \& Bianchi, 2011). The parent represents the original technological and managerial coreof the MNC (Zaheer \& Hernandez, 2011), provides subsidiaries with the practices, routines, and rules that guide decision-making processes, and shapes the subsidiary's ability to interpret and recombine externally acquired knowledge with internal resources and competencies. Beugelsdijk et al. (2018) confirm that firms tend to support foreign subsidiaries through the transfer of managerial and organizational processes, as both the headquarters unit and the 
subsidiaries benefit from the implementation of an integrated model in which the knowledge and best practices of multiple operations in different countries are shared.

Accordingly, the home-country cultural dimension is more likely to influence the subsidiary's ability to create novel connections between its knowledge base and the knowledge sourced from the partner. Consequently, alliance partners that come from countries other than the subsidiary's home country are likely to negatively affect the subsidiary's innovation performance, as subsidiaries struggle to successfully combine knowledge coming from culturally diverse domains (Savino et al., 2017). Subsidiaries tend to be exposed to distant interpretative schemes and approaches for a given problem, which leads to difficulties in reconceptualization and reduces their ability to successfully integrate the sourced knowledge with their own knowledge base. Hence, our second hypothesis is as follows:

Hypothesis 2. Cultural diversity between the allied partner and the MNC subsidiary's home country has a negative impact on the subsidiary's innovation performance.

\subsection{The moderating role of the explorative nature of strategic alliances}

A firm's decision to enter an alliance can be categorized by whether the firm wishes to exploit an existing capability or explore new opportunities. Explorative alliances aim to discover something new. In other words, they focus on the " $R$ " in the R\&D process and may lead to the development of new solutions. Explorative strategic alliances have largely been celebrated as fostering more innovation than exploitative alliances (Diestre \& Rajagopalan, 2012; Lavie \& Rosenkopf, 2006; Sampson, 2007). In the biotechnology industry, in particular, explorative collaborations are motivated by a desire to acquire basic knowledge 
that can be used to create novel molecular entities, which are then entered into the development and regulatory process (Rothaermel \& Deeds, 2004).

We claim that explorative alliances can moderate the previously discussed negative role of cultural diversity, as they may allow a partner to leverage those aspects of cultural diversity that are related to variety (Stahl et al., 2010) and stimulate creativity. Indeed, this may sustain the emergence of divergent processes in which the core is represented by the "value-in-diversity hypothesis" (Cox \& Blake, 1991, p.46). The extant literature shows that MNC subsidiaries' innovation activities stemming from explorative alliances benefit from cultural diversity between partners (Cox \& Blake, 2001). Indeed, “when firm engineers, employees, and inventors from different country locations come together to generate new knowledge, they are likely to draw on this diversity and bring together different perspectives and ideas from their local country environment” (Berry, 2014, p. 874). Conversely, singlecountry innovations are more likely to suffer from groupthink and the recycling of perspectives, routines, and ideas (Burt, 2004) from individuals with similar cultural backgrounds. Therefore, when subsidiaries and their partners are engaged in collaborative explorative activities, the coordination and knowledge-transfer issues characterizing the sourcing process tend to be balanced by the novelty and non-redundancy of the organizations' learning and cognitive processes (Eisenhardt \& Schoonhoven, 1996). Firms’ innovation routines tend to differ across national cultures (Bjorkman et al., 2007), and explorative alliances between partners located in culturally distant countries are likely to result in different resources and ideas being contributed to the collaboration, which can foster innovation (Sarala \& Vaara, 2010). Likewise, the benefits stemming from exposure to diverse cognitive schemes and routines make the costs of collaborating with partners that are culturally distant from the home country less relevant in explorative alliances. This enhances the ability of MNC subsidiaries to build new competencies that they do not inherit or receive 
from their parent companies, as well as their ability to develop new technical solutions (Christensen, 1997).

Therefore, we expect that when a strategic alliance is explorative in nature, cultural differences between the partners along with the host- and home-country dimensions of the MNC subsidiary will be less harmful for the subsidiary's innovative performances due to the benefits of diverse innovation schemes, models, and approaches. In other words, the explorative nature of an alliance has a positive moderating effect that reduces the negative relationship between cultural diversity and innovation. Accordingly, our third and fourth hypotheses are as follows:

Hypothesis 3. The impact of cultural diversity between the allied partner and the MNC subsidiary's host country is positively moderated by the explorative nature of the alliance.

Hypothesis 4. The impact of cultural diversity between the allied partner and the MNC subsidiary's home country is positively moderated by the explorative nature of the alliance.

\section{Methodology}

\subsection{Research setting and data}

Our research setting is the biotechnology industry. The industry's history can be traced back to 1953 when Watson and Crick discovered the double-helix model of DNA and to 1976 when the US company Genentech commercialized the first biotechnology product (Rothaermel, 2000). Our choice of this industry is justified by two main factors. First, the development of biotechnology solutions is largely characterized by inter-firm collaborations 
due to the necessity of integrating multiple and heterogeneous competencies. Second, these collaborations often involve actors located in distant countries, which makes cultural distance an important issue.

The sample, which comes from the BioScan database, covers 31 biotech MNC subsidiaries that established at least one strategic alliance between their foundation and 2010 . We considered all dyadic, non-equity-related collaborations in which each subsidiary was involved after the subsidiary was established in the host country. Overall, we considered 161 collaborations. Most of the alliances (i.e., 127, corresponding to almost 79\%) were established between 2000 and 2010. The oldest alliance was established in 1987. The average age of the subsidiaries at the time of the alliance's establishment was 21 years, although some differences existed across countries, with subsidiaries from Canada and Germany being younger (average of about six years) and subsidiaries from Belgium being older (average of about 48 years). With regard to firm size, the average number of employees was 5,327, with a range from an average of 20 in Canada and 80 in Germany to about 7,200 in the US.

In order to measure the innovativeness of MNC subsidiaries, we collected patent data from the USPTO database. As most of the subsidiaries considered were located in the US (63.35\%), the USPTO seemed to be the most suitable setting for this measure (Criscuolo, 2006). In addition, the US represents the largest market for biotechnology (Ernst \& Young, 2013). Finally, patents are effective mechanisms for protecting innovations in this industry (e.g., Phene et al., 2006), which increases the suitability of our proxy for capturing innovation performance.

We collected alliance-, subsidiary-, and partner-level data from multiple sources, including BioScan, Security and Exchange Commission (SEC) filings for publicly traded firms, press releases, and corporate websites. Table 1 illustrates the distribution of the 161 observations across the subsidiaries' host, home, and partner countries. 
- Insert Table 1 here -

\subsection{Variables}

Dependent variables. In line with previous studies (e.g., Phene \& Almeida, 2008), we measured both the quantity and quality of subsidiary innovativeness by analyzing each subsidiary's patent portfolio and the citations of that portfolio, respectively. More specifically, we measured Innovation quantity as the cumulated number of patents for which the subsidiary applied in the two years following the alliance's establishment. Innovation quality was measured as the total number of (forward) citations of these patents in the five years following each patent application. Patents and forward citations have widely been used to assess innovation performance, as they are relevant for estimating firms' innovative effort, and the technical and economic relevance of that effort (e.g., Gambardella, Harhoff, \& Verspagen, 2008; Messeni Petruzzelli et al., 2015), respectively.

Independent variables. To measure cultural diversity, we used the index proposed by Kogut and Singh (1998), which is based on the four cultural dimensions ${ }^{1}$ suggested by Hofstede (2001). This measure has been used in previous studies as a proxy for cultural differences between firms involved in international alliances (e.g., Barkema \& Vermuelen, 1997; Lavie \& Miller, 2008). More specifically, we measured cultural diversity between the focal subsidiary and each partner as follows:

CD subsidiary - partner $_{j}=\sum_{l=1}^{4} \frac{\left(I_{l, j}-I_{l, s}\right)^{2} / V_{l}}{4}$,

where $j$ is the country in which the $j_{t h}$ partner is located; $s$ is the country in which the subsidiary is located; $I_{l, j}$ is the score for the $l_{t h}$ cultural dimension; and $V_{l}$ is the variance in the

\footnotetext{
${ }^{1}$ Power distance, uncertainty avoidance, masculinity/femininity, and individualism.
} 
$l_{\text {th }}$ cultural dimension. Similarly, the cultural diversity between the subsidiary's parent country, $h$, and the partner's country, $j$, is measured as follows:

CD parent - partner $_{j}=\sum_{i=1}^{4} \frac{\left(I_{l, j}-I_{l, h}\right)^{2} / V_{l}}{4}$

The four dimension scores for each country were obtained from the website https://geerthofstede.com/national-culture.html.

Notably, 85 alliances (i.e., about $53 \%$ of the sample) involve partners located in the same country as the MNC subsidiary (i.e., the variable $C D$ subunit-partner equals 0 ). Eighty of these are US-US cases. At the same time, 27 alliances (i.e., 17\% of the sample) involve partners from the subsidiary's home country (i.e., the variable $C D$ parent-partner equals 0 ) and 22 of these are US-US cases.

Moderating variable. As in Koza and Lewin (2000), we identified the content of an alliance based on its announcements. In particular, we defined explorative alliances as those aimed at generating new knowledge, as in the case of $R \& D$ and new product development agreements. Exploitative alliances are defined as those agreements involving existing knowledge, such as agreements focused on joint marketing and services, original equipment manufacturing, and value-add resale, licensing, production, or supply (e.g., Lavie \& Rosenkopf, 2006; Rothaermel \& Deeds, 2004; Sampson, 2007). Thus, Explorative alliances is a dummy variable that takes a value of 1 in cases of explorative alliances and 0 otherwise. ${ }^{2}$ In our sample, 64 of the 161 observations (i.e., almost 40\%) were classified as explorative alliances.

\footnotetext{
2 This classification is based on the information found in BioScan on the content of the alliance. We coded the alliance as explorative when the content was explicitly defined as "R\&D" or "new product development," and as exploitative in all other cases.
} 
Control variables. We included several control variables at the subsidiary, partner, and alliance levels in order to account for other effects that might influence the innovation performance of MNC subsidiaries. More specifically, in line with previous studies (e.g., Almeida \& Phene, 2004), we introduced the following variables: Subsidiary size, measured as the number of employees; Subsidiary age, measured as the difference between the alliance year and subsidiary's year of establishment; Subsidiary technological capital, measured as the total number of patents the subsidiary filed with the USPTO prior to the year of the alliance's establishment; and Subsidiary alliance experience, measured as the number of alliances in which the subsidiary was involved before the year of the alliance.

In addition, we controlled for the Technological distance between the alliance partners. In this regard, we followed Diestre and Rajagopalan (2012) in identifying all USPTO patents and related technological classes filed by each subsidiary and its partner until the alliance year. This allowed us to create a count of the number of main patent classes in which both firms had overlapping patenting activities. Technological distance was computed as the negative value of this count, such that 0 corresponds to the maximum technological distance.

Moreover, we included the variable Partners' technological capital by calculating the number of patents held by each alliance partner before the collaboration date. ${ }^{3}$ In addition, we accounted for the relative technological intensity of the subsidiary and partner countries by employing the variable Subsidiary-partner countries technology ratio. We computed this variable as the ratio between the number of patents in the subsidiary's host country relative to its gross domestic product (GDP) and the number of patents in the partner's home country relative to its GDP. We also controlled for the size of each subsidiary's alliance portfolio using the variable Portfolio size, which we computed as the total number of alliances

\footnotetext{
${ }^{3}$ We standardized the proxies for the variables Subsidiary size, Subsidiary technological capital, and Partners' technological capital in order to ease the interpretation of regression coefficients.
} 
established by each subsidiary each year. We accounted for the entry mode used to establish the subsidiary by employing the dummy variable Acquisition entry mode, which was assigned a value of 1 if the subsidiary was set up through an acquisition and 0 if it was established as a greenfield operation.

In order to control for the institutional context of the host country, we employed the variable Institutional quality, which we measured using the World Bank's regulatory quality indicator, which is defined as the "perceptions of the ability of the government to formulate and implement sound policies and regulations that permit and promote private sector development."4 Finally, we controlled for the status of the partner company using the variable Independent partner, which is a dummy set equal to 1 when the allied partner is independent and 0 when it is controlled by another company.

\subsection{Estimation model}

As our dependent variable is a count, an integer, and non-negative, the Negative Binomial approach is the more suitable than a Poisson Model (Hausman, Hall, \& Griliches, 1984). The latter assumes an equal value between the standard deviation and the mean, which is violated by both our variables, as the coefficients of variation for Innovation quantity and Innovation quality are 2.37 and 2.19 , respectively. Table 2 presents the correlation matrix and descriptive statistics for our variables. As some correlation coefficients are greater than 0.5 , we computed the maximum variance inflation factor (VIF) to check for multicollinearity issues. As relevant values did not exceed the critical threshold of 10 , we can arguably rule out multicollinearity concerns (Kleinbaum et al., 1998).

- Insert Table 2 here -

\footnotetext{
${ }^{4}$ This is the official definition provided by the World Bank Data Catalog for the variable Regulatory quality (https://datacatalog.worldbank.org/regulatory-quality-estimate-0).
} 


\section{Results}

Tables 3 and 4 present the findings of our analysis for Innovation quantity and Innovation quality, respectively. More specifically, we report the estimated coefficients, p-values (in brackets), and incidence rate ratios (IRR $)^{5}$ in order to gain more insights into the effect sizes of relevant estimated coefficients.

Column (1) of both tables displays the results of the base model. With regard to the controls, the positive and significant coefficient of Subsidiary size $(\mathrm{p}<0.01)$ in Table 3 indicates that larger firms perform better in terms of innovation quantity, probably because they can afford to embark on larger-scale projects. Table 3 also shows that newer subsidiaries seem to outperform older ones, as indicated by the negative and significant coefficient of Subsidiary age $(\mathrm{p}<0.10)$. Both Tables 3 and 4 show a strong positive effect of Subsidiary technological capital on the dependent variables ( $\mathrm{p}<0.01$ in Tables 3 and 4$)$, which suggests a strong, cumulative effect of innovation activity. Moreover, a weak positive effect of Subsidiary alliance experience $(\mathrm{p}<0.10)$ emerges in Table 4 . Conversely, the variable Technological distance shows a negative and significant effect on both innovation quantity and quality ( $p<0.01$ in Tables 3 and 4), which reveals that firms benefit more when they ally with partners that are not engaged in highly different technological activities.

Similarly, Partners' technological capital has a negative and significant effect for both Innovation quantity ( $\mathrm{p}<0.01$ in Table 3$)$ and Innovation quality $(\mathrm{p}<0.10$ in Table 4$)$. This suggests that having an overly innovative partner might constrain the subsidiary's innovation activity. Subsidiary-partner countries technology ratio displays a positive and significant effect on both Innovation quantity ( $<$ < 0.10) and Innovation quality ( 10.01 in Table 4), while Portfolio size only has a negative effect on Innovation quantity ( $\mathrm{p}<0.05$ in Table 3), probably due to the increase in coordination costs. Finally, both the entry mode and the

\footnotetext{
${ }^{5}$ IRR is the ratio of two incident rates. The incident rate provides a measure of the frequency with which an event occurs in a population over a period of time.
} 
partner's ownership status have a strong effect on innovation activity. With regard to the former, subsidiaries established through acquisitions are more likely to have higher innovation quantity and quality than those established as greenfield operations, as shown by the strong positive coefficient for Acquisition entry mode in both tables $(\mathrm{p}<0.01)$. Finally, innovative performance seems to improve when the partner company is also a (domestic or foreign) subsidiary of another firm, as the variable Independent partner is negatively and significantly associated with both measures of innovation in Tables 3 and 4 ( $p<0.01$ ).

With respect to the effects exerted by cultural diversity, Column 1 of Tables 3 and 4 shows a significant, negative effect of $C D$ subsidiary-partner on both Innovation quantity and Innovation quality ( $\mathrm{p}<0.01$ in both tables), which provides full support for Hypothesis 1. More specifically, the IRR shows that each additional unit of cultural diversity between the subsidiary and the partner company reduces the number of patents (i.e., the quantity of innovation) by about $29 \%$ and the number of forward citations (i.e., the quality of innovation) by about $34 \%$.

Hypothesis 2 is supported only for Innovation quality, as cultural diversity between the parent's home country and the partner's country shows a negative and significant impact only in Column 1 of Table 4 ( $\mathrm{p}<0.05$ ). The IRR suggests that each additional unit of cultural diversity between the parent and the partner reduces the number of forward citations by about $27 \%$.

Columns (2) and (3) report the tests of Hypotheses 3 and 4, respectively. In those models, we introduced the interaction between Explorative alliances and CD subsidiarypartner (column (2)) and the interaction between Explorative alliances and CD parentpartner (columns (3)), respectively. Specifically, the coefficient of the interaction term between Explorative alliances and CD subsidiary-partner is positive and significant for both Innovation quantity and Innovation quality ( $\mathrm{p}<0.01$ in Tables 3 and 4), which supports 
Hypothesis 3. At the same time, Column (3) of Tables 3 and 4 displays a positive and significant coefficient for the interaction between Explorative alliances and CD parentpartner $(\mathrm{p}<0.01$ for innovation quantity; $\mathrm{p}<0.05$ for innovation quality), which supports Hypothesis 4. In this case, the IRR cannot be directly employed to interpret the magnitude of the coefficient (Hilbe, 2008).

- Insert Tables 3 and 4 here -

In order to gain more insight into Hypotheses 3 and 4, we plotted the significant results by using the coefficient estimates (Zelner, 2009). Figures 1 and 2 confirm that innovation quantity and quality, respectively, are less affected by cultural diversity between the subsidiary and the partner in explorative alliances, being the slope of the line associated to the latter less negative in both Figures 1 and 2. We also plotted the result of the interaction between explorative alliances and cultural distance between partner and parent. Figures 3 and 4 show that the slopes of the lines accounting for the relationship between (parent-partner) cultural diversity and innovation quantity and quality, respectively, are positive for explorative alliances.

- Insert Figures 1, 2, 3 and 4 here -

\section{Discussion and conclusion}

In this study, we analyzed the impact of cultural diversity on the innovation performance of MNC subsidiaries, which stems from their abilities to source knowledge through alliance partners and to recombine that knowledge with knowledge held internally. Accordingly, we considered the role of multicultural diversity in light of the dual-culture background of MNC subsidiaries, which encompasses a host-country and a home-country dimension. More specifically, we claim the host-country dimension to affect the sourcing of external knowledge, while the home-country dimension to influence subsidiaries' abilities to 
recombine knowledge with the MNC knowledge base.

Our results revealed that subsidiary innovativeness is hampered when subsidiaries collaborate with partners from countries other than their host and home countries. Moreover, while the host-country cultural dimension affects both innovation quantity and quality, the home-country cultural dimension seems to affect only innovation quality. These negative effects are mainly due to the lack of common social norms, values, and beliefs, as well as the presence of different interpretative routines and schemes, which reduce the effectiveness of knowledge sourcing and recombination. In addition, our research demonstrates that the net balance between the costs and benefits of cultural diversity is contingent on the nature of the alliance. In this regard, we find that for subsidiaries involved in explorative alliances, knowledge sourcing and recombination become more sensitive to the creativity and variety aspects of cultural diversity, which allow them to pool different knowledge, ideas, perspectives, problem-solving approaches, cognitive schemes, and routines. In other words, in these circumstances, the benefits associated with cultural diversity partially offset its costs, making it a resource that can help sustain subsidiaries' innovativeness, especially in the recombination process where the effect of cultural diversity may even be positive.

We believe our study sheds new light on a number of theoretical issues. First, we contribute to the international business and innovation literature by responding to the recent call to analyze differences in terms of innovative performance across MNC subsidiaries (Cantwell and Piscitello, 2014) and by focusing on how subsidiaries leverage strategic alliances to create new technological solutions. This twofold contribution is in line with an emerging line of inquiry on the role of internal and external networks in MNC innovation (Zaheer \& Hernandez, 2011). Accordingly, we extend our understanding of the joint impact of MNC subsidiaries' internal and external networks on their innovation performance (Anderson et al., 2002) by emphasizing the existence of a dual-culture background. While 
typical cross-border alliance between two firms located in their home countries suffer a "simple" double-layered acculturation (Barkema et al., 1996), a cross-border strategic alliance between two MNC subsidiaries entails more complexities due to the subsidiaries' dual-culture backgrounds, which raises the challenge of a "multi-layered acculturation."

Our disentanglement of the dual-culture background of subsidiaries allows us to make a second important contribution to the strategic alliance literature in general and to the RDT in particular. Specifically, our findings support the need to include the cultural context when considering cross-border alliances (Steensma et al., 2000). Our research confirms that the extent to which a firm can rely on external resources to increase its innovativeness is influenced by cultural diversity, which is likely to affect knowledge accessibility and the effectiveness of knowledge acquisition between partners (Inkpen, 2000). We extend this perspective by showing that when one of the alliance partners is a subsidiary, cultural diversity should be assessed not only between the partners (as detrimental in the knowledgesourcing phase) but also with respect to the home country (as detrimental in the knowledgerecombination phase). We provide an additional contribution by showing that certain types of alliances can offset these negative effects — cultural diversity becomes less of a concern (or even an advantage) when a strategic alliance is explorative in nature.

Third, we provide new evidence on the impact of cultural differences between partners on performance (Bjorkman et al., 2007; Lee et al., 2017). By showing how the impact of diversity is moderated by the nature of an alliance, we offer novel insights that can help improve the quality of cross-cultural research and contribute to explaining the "paradox" of cultural distance (Bell and Zaheer, 2007).

Our study also has several managerial implications. For instance, our study informs managers and corporate executives operating in subsidiaries of high-technology MNCs about the costs and benefits of collaborating with culturally different partners. More specifically, 
ceteris paribus, our findings confirm the negative effect of cultural diversity on innovation performance. However, the situation may change when subsidiaries establish explorative agreements focused on searching novel domains, as the impact of cultural differences is dampened in such cases.

Our study suffers from a number of limitations that may pave the way for additional research. First, in order to assess subsidiaries' innovative performance, we rely on patentbased information, which gives rise to a number of concerns despite its extensive use in empirical studies. Therefore, we point to a need for similar research using alternative proxies. Second, we investigate the interplay between partners' cultural diversity and the explorative nature of alliances, and its effect on subsidiaries' innovative performance. However, other dimensions of partners' diversity may be considered, such as functional, industrial, and organizational diversity. Moreover, more fine-grained classifications of the nature of alliances could be examined by, for example, better disentangling the exploitative types of alliances. Third, even though Hofstede's approach is widely used in the literature to evaluate cultural differences, it has also been subject to several criticisms (e.g., Javidan et al., 2006). Therefore, future studies may use different variables or develop novel measures to assess cultural diversity in an attempt to uncover a more comprehensive proxy. In particular, a more finegrained measure of cultural diversity could be employed to account for the differences within (rather than across) countries. Alternatively, a time-variant measure together with a panel data-approach could be applied to account for the social changes underlying the evolution of cultures and for the variation of innovation over time. Finally, as our research focuses on a high-technology industry (i.e., biotechnology), additional analyses that include other sectors are required before the generalizability of our findings can be determined. 


\section{References}

Almeida, P., \& Phene, A. (2004). Subsidiaries and knowledge creation: The influence of the MNC and host country on innovation. Strategic Management Journal, 25(8-9), 847-864.

Anderson, U., Forsgren, M., \& Holm, U. (2002). The strategic impact of external networks: Subsidiary performance and competence development in the multinational corporation. Strategic Management Journal, 23(11), 979-996.

Barkema, H. G., \& Vermuelen, F. (1997). What differences in the cultural backgrounds of partners are detrimental for international joint ventures? Journal of International Business Studies, 28(4), 845-864.

Barkema, H. G., Bell, J. H., \& Pennings, J. M. (1996). Foreign entry, cultural barriers and learning. Strategic Management Journal, 17(2), 151-166.

Bartholomew, S. (1997). National systems of biotechnology innovation: Complex interdependence in the global system. Journal of International Business Studies, 28(2), 241266.

Bell, G. G., \& Zaheer, A. (2007). Geography, networks, and knowledge flow. Organization Science, 18(6), 955-972.

Berry, H. (2014). Global integration and innovation: Multi-country knowledge generation within MNCs. Strategic Management Journal, 35(6), 869-890.

Beugelsdijk, S., Kostova, T., Kunst, V. E., Spadafora, E., \& van Essen, M. (2018). Cultural Distance and Firm Internationalization: A Meta-Analytical Review and Theoretical Implications. Journal of Management, 44(1), 89-130.

Bjorkman, I., Stahl G. K., \& Vaara, E. (2007). Cultural difference and capability transfer in cross-border acquisitions: The mediating roles of capability complementarity, absorptive capacity and social integration. Journal of International Business Studies, 38(4), 658-672. Burt, R. S. (2004). Structural holes and good ideas. American Journal of Sociology, 110(2), 
349-399.

Cantwell, J., \& Piscitello, L. (2014). Historical changes in the determinants of competence creation in MNC subunits: the increasing role of international knowledge. Industrial and Corporate Change, 23(3), 633-660.

Capaldo, A., \& Messeni Petruzzelli, A. (2014). Partner geographic and organizational proximity and the innovative performance of knowledge - creating alliances. European Management Review, 11(1), 63-84.

Christensen, C. M. (1997). The Innovator's Dilemma: When New Technologies Cause Great Firms to Fail. Cambridge, MA: Harvard Business School Press.

Cohen, W. M., \& Levinthal, D. A. (1990). Absorptive Capacity: A New Perspective on Learning and Innovation. Administrative Science Quarterly, 35(1), 128-152.

Contractor, F., \& Lorange P. (2002). The growth of alliances in the knowledge-based economy. International Business Review, 11(4), 485-502.

Cox, T. H., \& Blake, S. (1991). Managing cultural diversity: Implications for organizational competitiveness. Academy of Management Executive, 5(3), 45-56.

Criscuolo, P. (2006). The 'home advantage' effect and patent families. A comparison of OECD triadic patents, the USPTO and the EPO. Scientometrics, 66(1), 23-41.

Das, T.K., \& Teng, B. S. (1998). Between trust and control: Developing confidence in partner cooperation in alliances. Academy of Management Review, 23(3), 491-512.

Di Minin, A., \& Bianchi, M. (2011). Safe nests in global nets: Internalization and appropriability of R\&D in wireless telecom. Journal of International Business Studies, 42(7): 910-934.

Diestre, L., \& Rajagopalan, N. (2012). Are all 'sharks' dangerous? New biotechnology ventures and partner selection in R\&D alliances. Strategic Management Journal, 33(10), 1115-1134. 
Eisenhardt, K. M., \& Schoonhoven, C. B. (1996). Resource-based view of strategic alliance formation: strategic and social effects in entrepreneurial firms. Organization Science, 7(2), $136-150$.

Ernst \& Young (2013). Global Biotechnology Report 2013. San Francisco, CA: Technology Group.

Galunic, C. D., \& Rodan, S. (1998). Resource recombinations in the firm: knowledge structures and the potential for Schumpeterian innovation. Strategic Management Journal, 19(12), 1193-1209.

Gambardella, A., Harhoff, D., \& Verspagen, B. (2008). The Value of European Patent. European Management Review, 5(2), 69-84.

Gulati, R. (1999). Network location and learning: The influence of network resources and firm capabilities on alliance formation. Strategic Management Journal, 20(5), 397-420. Hausman, J., Hall, B., \& Griliches, Z. (1984). Econometric models for count data with an application to the patents—R\&D relationship. Econometrica, 52(4), 909-938.

Hilbe, J. M. (2008). Brief overview on interpreting count model risk ratios: an addendum to negative binomial regression. Cambridge, UK: Cambridge University Press.

Hoffman, W. H., \& Schlosser, R. (2001). Success factors of strategic alliances in small and medium-sized enterprises-an empirical survey. Long Range Planning, 34(3), 357 - 381. Hofstede, G. (2001). Culture's consequences: Comparing values, behaviors, institutions and organizations across nations ( $2^{\text {nd }}$ ed.). Thousand Oaks, CA: Sage.

Inkpen, A. C. (2000). Learning through joint ventures: a framework of knowledge acquisition. Journal of Management Studies, 37(7), 1019-1044.

Javidan, M., House, R. J., Dorfman, P. W., Hanges, P. J., \& de Luque, M. S. (2006). Conceptualizing and measuring cultures and their consequences: A comparative review of GLOBE's and Hofstede's approaches. Journal of International Business Studies, 37(6), 897- 
914.

Kleinbaum, D. G., Lawrence, L. K., Muller, K. E., \& Nizam, A. (1998). Applied regression analysis and other multivariable methods. Pacific Grove, CA: Brooks/Cole.

Kogut, B., \& Singh, H. (1988). The effect of national culture on the choice of entry mode. Journal of International Business Studies, 19(3), 411-432.

Kogut, B., \& Zander, U. (1992). Knowledge of the firm, combinative capabilities, and the replication of technology. Organization Science, 3(3), 383-397.

Koza, M. P., \& Lewin, A. Y. (2000). Managing partnerships and strategic alliances: Raising the odds of success. European Management Journal, 18(2), 146-151.

Lavie, D., \& Miller, S. R. (2008). Alliance portfolio internationalization and firm performance. Organization Science, 19(4), 623-646.

Lavie, D., \& Rosenkopf, L. (2006). Balancing exploration and exploitation in alliance formation. Academy of Management Journal, 49(4), 797-818.

Lee, D., Kirkpatrick-Husk, K., \& Madhavan, R. (2017). Diversity in alliance portfolios and performance outcomes: A meta-analysis. Journal of Management, 43(5), 1472-1497. Li, Y., \& Vanhaverbeke, W. (2009). The effects of interindustry and country difference in supplier relationships on pioneering innovations. Technovation, 29(12), 843-858.

Lyles, M. A., \& Salk, J. E. (1996). Knowledge acquisition from foreign parents in international joint ventures: An empirical examination in the Hungarian context. Journal of International Business Studies, 27(5), 877-903.

Messeni Petruzzelli, A., Rotolo, D., \& Albino, V. (2015). Determinants of patent citations in biotechnology: An analysis of patent influence across the industrial and organizational boundaries. Technological Forecasting \& Social Change, 91, 208-221.

Messeni Petruzzelli, A., \& Savino, T. (2014). Search, Recombination, and Innovation: Lessons from the Haute Cuisine. Long Range Planning, 47(4), 224-238. 
Milliken, F., Bartel, B., \& Kurtzberg, J. (2003). Diversity and creativity in work groups: A dynamic perspective on the affective and cognitive processes that link diversity and performance. In P. Paulus, \& B. Nijstad (Eds.), Group creativity: Innovation through collaboration, (pp. 32-62). Oxford, UK: Oxford University Press.

Monteiro, L. F., \& Birkinshaw, J. (2017). The external knowledge sourcing process in multinational corporations. Strategic Management Journal, 38(2), 342-362.

Mowery, D. C., Oxley, J. E., \& Silverman, B. S. (1996). Strategic alliances and interfirm knowledge transfer. Strategic Management Journal Special Winter Special Issue, 17, 77-91. Olk, P. (1997). The effect of partner differences on the performance of R\&D consortia. In P., Beamish, \& J., Killings (Eds.), Cooperative Strategies, North American Perspectives (pp. 133- 159). San Francisco, CA: New Lexington Press.

Palich, L., \& Gomez-Mejia, L. (1999). A theory of global strategy and firm efficiencies: considering the effects of cultural diversity. Journal of Management Studies, 25(4), 587-606. Pfeffer, J., \& Salancik, G. R. (1978). The External Control of Organizations: A Resource Dependence Perspective. New York: Harper \& Row.

Phene, A., \& Almeida, P. (2008). Innovation in multinational subsidiaries: The role of knowledge assimilation and subsidiary capabilities. Journal of International Business Studies, 39(5), 901-919.

Phene, A., Fladmoe-Lindquist, K., \& Marsh, L. (2006). Breakthrough innovations in the U.S. biotechnology industry: The effects of technological space and geographic origin'. Strategic Management Journal, 27(4), 369-388.

Prahalad, C. K., \& Bettis, R. A. (1986). The dominant logic: A new linkage between diversity and performance. Strategic Management Journal, 7(6), 485-501.

Reuer, J. J., \& Lahiri, N. (2014). Searching for alliance partners: Effects of geographic distance on the formation of R\&D collaborations. Organization Science, 25(1), 283-298. 
Rothaermel, F. T. (2000). Technological discontinuities and the nature of competition.

Technology Analysis \& Strategic Management, 12(2), 149-160.

Rothaermel, F. T., \& Deeds, D. L. (2004). Exploration and exploitation alliances in

biotechnology: A system of new product development. Strategic Management Journal, 25(3), 201-221.

Sampson, R. C. (2007). R\&D alliances and firm performance: The impact of technological diversity and alliance organization on innovation. Academy of Management Journal, 50(2), 364-386.

Sarala, R. M., \& Vaara, E. (2010). Cultural differences, convergence, and crossvergence as explanations of knowledge transfer in international acquisitions. Journal of International Business Studies, 41(8), 1365-1390.

Savino, T., Messeni Petruzzelli, A., \& Albino, V. (2017). Recombination and search: the mechanism to create innovation. A literature review. International Journal of Management Reviews, 19(1), 54-75.

Schilling, M. A., \& Green, E. (2011). Recombinant search and breakthrough idea generation: An analysis of high impact papers in the social sciences. Research Policy, 40(10), 1321-1331. Schmidt, T., \& Sofka, W. (2009). Liability of foreignness as a barrier to knowledge spillovers: lost in translation? Journal of International Management, 15(4), 460 - 474. Shenkar, O. (2012). Beyond cultural distance: Switching to a friction lens in the study of cultural difference. Journal of International Business Study, 43(1), 12-17.

Sirmon, D. G., \& Lane, P. J. (2004). A model of cultural differences and international alliance performance. Journal of international Business Studies, 35(4): 306-319.

Smale, A., Bjorkman, I., Ehrnrooth, M., John, S., Makela, K., \& Sumelius, J. (2015). Dual values-based organizational identification in MNC subsidiaries: A multilevel study. Journal of International Business Studies, 46(7), 761-783. 
Stahl, G. K., Maznevski, M. L., Voigt, A., \& Jonsen, K. (2010). Unraveling the effects of cultural diversity in teams: A meta-analysis of research on multicultural work groups. Journal of International Business Studies, 41(4), 690-709.

Steensma, H. K., Marino, L., Weaver, K. M., \& Dickson, P. H. (2000). The influence of national culture on the formation of technology alliances by entrepreneurial firms. Academy of Management Journal, 43(5), 951-973.

Tiemessen, I., Lane, H. W., Crossan, M. M., \& Inkpen, A. C. (1997). Knowledge management in international joint ventures. In P. Beamish, \& J. Killings (Eds.), Cooperative Strategies, North American Perspectives (pp. 370-399) San Francisco, CA: New Lexington Press.

West, M. A. (2002). Sparkling fountains or stagnant ponds: An integrative model of creativity and innovation implementations in work groups. Applied Psychology: An International Review, 51(3), 355-424.

Zaheer, A., \& Hernandez, E. (2011). The geographic scope of the MNC and its alliance portfolio: Resolving the paradox of distance. Global Strategy Journal, 1(1-2), 109-126. Zelner, B. A. (2009). Using simulation to interpret results from Logit, Probit, and other nonlinear models. Strategic Management Journal, 30(12), 1335-1348.

Zeng, Y., Shenkar, O., Leec, S. H., \& Song, S. (2013). Cultural differences, MNE learning abilities, and the effect of experience on subsidiary mortality in a dissimilar culture: Evidence from Korean MNEs. Journal of International Business Studies, 44(1), 42-65. 


\section{Tables}

Table 1: Distribution of observations by subsidiary host country, subsidiary parent country, and the country of origin of the alliance partners

\begin{tabular}{lcccccc}
\hline \multirow{2}{*}{ Countries } & \multicolumn{2}{c}{ Subsidiary } & \multicolumn{2}{c}{ Parent } & \multicolumn{2}{c}{ Partner } \\
\cline { 2 - 7 } & No. & \% & No. & $\%$ & No. & \% \\
\hline Australia & - & - & 1 & 0.62 & 1 & 0.62 \\
Austria & - & - & - & - & 1 & 0.62 \\
Belgium & 28 & 17.39 & 6 & 3.73 & 1 & 0.62 \\
China & - & - & - & - & 1 & 0.62 \\
Canada & 1 & 0.62 & 4 & 2.48 & - & - \\
Denmark & - & - & 1 & 0.62 & 2 & 1.24 \\
France & - & - & 6 & 3.73 & 1 & 0.62 \\
Germany & 12 & 7.45 & 25 & 15.53 & 14 & 8.7 \\
Japan & - & - & 23 & 14.29 & 6 & 3.73 \\
Ireland & 1 & 0.62 & - & - & - & - \\
Israel & 4 & 2.48 & - & - & - & - \\
Mexico & - & - & 2 & 1.24 & - & - \\
Netherlands & - & - & 6 & 3.73 & 1 & 0.62 \\
Sweden & - & - & - & - & 3 & 1.86 \\
Switzerland & - & - & 35 & 21.74 & 2 & 1.24 \\
UK & 13 & 8.07 & 18 & 11.18 & 12 & 7.45 \\
US & 102 & 63.35 & 34 & 21.12 & 116 & 72.05 \\
\hline Total & $\mathbf{1 6 1}$ & $\mathbf{1 0 0 . 0 0}$ & $\mathbf{1 6 1}$ & $\mathbf{1 0 0 . 0 0}$ & $\mathbf{1 6 1}$ & $\mathbf{1 0 0 . 0 0}$ \\
\hline
\end{tabular}


Table 2: Correlation matrix and descriptive statistics

\begin{tabular}{|c|c|c|c|c|c|c|c|c|c|c|c|c|c|c|c|c|c|}
\hline & & 1) & 2) & 3) & 4) & 5) & 6) & 7) & 8) & 9) & 10) & 11) & 12) & 13) & 14) & 15) & 16) \\
\hline 1) & Innovation quantity & 1.000 & & & & & & & & & & & & & & & \\
\hline 2) & Innovation quality & 0.501 & 1.000 & & & & & & & & & & & & & & \\
\hline 4) & CD subsidiary-partner & -0.070 & 0.033 & 1.000 & & & & & & & & & & & & & \\
\hline 5) & CD parent-partner & -0.086 & -0.089 & 0.006 & 1.000 & & & & & & & & & & & & \\
\hline 3) & Explorative alliances & 0.021 & 0.028 & 0.084 & 0.094 & 1.000 & & & & & & & & & & & \\
\hline 6) & Subsidiary size & 0.162 & 0.104 & -0.136 & -0.269 & -0.035 & 1.000 & & & & & & & & & & \\
\hline 7) & Subsidiary age & 0.060 & 0.077 & 0.293 & -0.298 & -0.071 & 0.089 & 1.000 & & & & & & & & & \\
\hline 8) & Subsidiary technological capital & 0.503 & 0.558 & -0.045 & -0.159 & 0.003 & 0.387 & 0.331 & 1.000 & & & & & & & & \\
\hline 9) & Subsidiary alliance experience & 0.205 & 0.358 & 0.156 & -0.122 & -0.126 & 0.194 & 0.324 & 0.484 & 1.000 & & & & & & & \\
\hline 10) & Technological distance & -0.495 & -0.472 & -0.027 & 0.007 & -0.149 & -0.114 & -0.200 & -0.394 & -0.165 & 1.000 & & & & & & \\
\hline 11) & Partners' technological capital & -0.038 & 0.009 & 0.010 & 0.028 & 0.108 & -0.113 & -0.063 & -0.120 & -0.108 & -0.145 & 1.000 & & & & & \\
\hline 12) & Countries technology ratio & -0.004 & 0.038 & 0.303 & 0.061 & -0.107 & -0.007 & 0.044 & 0.002 & 0.089 & -0.034 & -0.065 & 1.000 & & & & \\
\hline 13) & Portfolio size & 0.123 & 0.177 & -0.089 & -0.131 & -0.005 & 0.124 & -0.054 & 0.199 & 0.046 & -0.032 & -0.080 & -0.124 & 1.000 & & & \\
\hline 14) & Acquisition entry mode & 0.246 & 0.270 & 0.177 & -0.200 & 0.107 & -0.378 & 0.427 & 0.254 & 0.324 & -0.279 & 0.045 & -0.115 & 0.176 & 1.000 & & \\
\hline 15) & Institutional quality & 0.126 & 0.108 & -0.506 & 0.315 & 0.134 & 0.060 & -0.448 & 0.074 & -0.289 & -0.088 & 0.057 & -0.352 & 0.080 & -0.005 & 1.000 & \\
\hline 16) & Independent partner & 0.013 & -0.071 & 0.074 & 0.105 & 0.177 & -0.136 & 0.099 & 0.056 & 0.088 & -0.048 & 0.120 & -0.037 & -0.024 & 0.241 & 0.023 & 1.000 \\
\hline \multicolumn{2}{|c|}{ Observations } & 161 & 161 & 161 & 161 & 161 & 161 & 161 & 161 & 161 & 161 & 161 & 161 & 161 & 161 & 161 & 161 \\
\hline \multicolumn{2}{|c|}{ Mean } & 29.255 & 39.248 & 0.626 & 0.966 & 0.398 & 0.098 & 20.845 & 0.584 & 12.559 & -1.137 & -0.023 & 1.257 & 3.280 & 0.739 & 1.519 & 0.646 \\
\hline \multicolumn{2}{|c|}{ Std. dev. } & 69.237 & 86.089 & 0.989 & 1.094 & 0.491 & 0.863 & 17.745 & 1.824 & 11.804 & 1.563 & 0.928 & 1.443 & 2.239 & 0.440 & 0.153 & 0.480 \\
\hline \multicolumn{2}{|c|}{ Min. } & 0.000 & 0.000 & 0.000 & 0.000 & 0.000 & -0.516 & 0.000 & -0.445 & 0.000 & -5.000 & -0.323 & 0.290 & 1.000 & 0.000 & 1.050 & 0.000 \\
\hline \multicolumn{2}{|c|}{ Max. } & 623.000 & 483.000 & 4.757 & 3.513 & 1.000 & 2.175 & 66.000 & 5.735 & 45.000 & 0.000 & 5.842 & 14.809 & 9.000 & 1.000 & 1.790 & 1.000 \\
\hline
\end{tabular}


Table 3: Results of the negative binomial models for Innovation quantity

\begin{tabular}{|c|c|c|c|c|c|c|}
\hline \multirow{3}{*}{ Explanatory variables } & \multicolumn{6}{|c|}{ Innovation quantity } \\
\hline & \multicolumn{2}{|c|}{ (1) } & \multicolumn{2}{|c|}{$(2)$} & \multicolumn{2}{|c|}{ (3) } \\
\hline & Coefficient & IRR & Coefficient & IRR & Coefficient & IRR \\
\hline CD subsidiary-partner & $\begin{array}{c}-0.342 * * * \\
(-3.13)\end{array}$ & $\begin{array}{c}0.711 * * * \\
(-3.13)\end{array}$ & $\begin{array}{c}-0.805 * * * \\
(-5.81)\end{array}$ & $\begin{array}{c}0.447 * * * \\
(-5.81)\end{array}$ & $\begin{array}{c}-0.427 * * * \\
(-2.89)\end{array}$ & $\begin{array}{c}0.652 * * * \\
(-2.89)\end{array}$ \\
\hline CD parent-partner & $\begin{array}{l}0.025 \\
(0.14)\end{array}$ & $\begin{array}{l}1.026 \\
(0.14)\end{array}$ & $\begin{array}{l}-0.017 \\
(-0.09)\end{array}$ & $\begin{array}{c}0.983 \\
(-0.09)\end{array}$ & $\begin{array}{c}-0.622 * * * \\
(-3.35)\end{array}$ & $\begin{array}{c}0.537 * * * \\
(-3.35)\end{array}$ \\
\hline Explorative alliances & $\begin{array}{l}0.315 \\
(0.78)\end{array}$ & $\begin{array}{l}1.370 \\
(0.78)\end{array}$ & $\begin{array}{l}0.091 \\
(0.20)\end{array}$ & $\begin{array}{l}1.095 \\
(0.20)\end{array}$ & $\begin{array}{c}-0.693 * * \\
(-2.22)\end{array}$ & $\begin{array}{c}0.500 * * \\
(-2.22)\end{array}$ \\
\hline Subsidiary size & $\begin{array}{c}1.540 * * * \\
(4.04)\end{array}$ & $\begin{array}{c}4.663 * * * \\
(4.04)\end{array}$ & $\begin{array}{c}1.544 * * * \\
(3.86)\end{array}$ & $\begin{array}{c}4.681 * * * \\
(3.86)\end{array}$ & $\begin{array}{c}1.604 * * * \\
(3.20)\end{array}$ & $\begin{array}{c}4.974 * * * \\
(3.20)\end{array}$ \\
\hline Subsidiary age & $\begin{array}{c}-0.041 * \\
(-1.87)\end{array}$ & $\begin{array}{l}0.960 * \\
(-1.87)\end{array}$ & $\begin{array}{c}-0.045^{* *} \\
(-2.06)\end{array}$ & $\begin{array}{c}0.956 * * \\
(-2.06)\end{array}$ & $\begin{array}{c}-0.039 * \\
(-1.72)\end{array}$ & $\begin{array}{l}0.962 * \\
(-1.72)\end{array}$ \\
\hline Subsidiary technological capital & $\begin{array}{c}0.576^{* * *} \\
(6.23)\end{array}$ & $\begin{array}{c}1.779 * * * \\
(6.23)\end{array}$ & $\begin{array}{c}0.565 * * * \\
(6.44)\end{array}$ & $\begin{array}{c}1.760 * * * \\
(6.44)\end{array}$ & $\begin{array}{c}0.514 * * * \\
(4.96)\end{array}$ & $\begin{array}{c}1.673 * * * \\
(4.96)\end{array}$ \\
\hline Subsidiary alliance experience & $\begin{array}{l}-0.016 \\
(-1.14)\end{array}$ & $\begin{array}{c}0.984 \\
(-1.14)\end{array}$ & $\begin{array}{l}-0.016 \\
(-1.00)\end{array}$ & $\begin{array}{c}0.984 \\
(-1.00)\end{array}$ & $\begin{array}{l}-0.016 \\
(-0.84)\end{array}$ & $\begin{array}{c}0.984 \\
(-0.84)\end{array}$ \\
\hline Technological distance & $\begin{array}{c}-0.806 * * * \\
(-6.31)\end{array}$ & $\begin{array}{c}0.447 * * * \\
(-6.31)\end{array}$ & $\begin{array}{c}-0.771 * * * \\
(-5.83)\end{array}$ & $\begin{array}{c}0.463 * * * \\
(-5.83)\end{array}$ & $\begin{array}{c}-0.715^{* * *} \\
(-6.10)\end{array}$ & $\begin{array}{c}0.489 * * * \\
(-6.10)\end{array}$ \\
\hline Partners' technological capital & $\begin{array}{c}-0.495 * * * \\
(-4.03)\end{array}$ & $\begin{array}{c}0.609 * * * \\
(-4.03)\end{array}$ & $\begin{array}{c}-0.455 * * * \\
(-3.62)\end{array}$ & $\begin{array}{c}0.635 * * * \\
(-3.62)\end{array}$ & $\begin{array}{c}-0.429 * * * \\
(-3.26)\end{array}$ & $\begin{array}{c}0.651 * * * \\
(-3.26)\end{array}$ \\
\hline Subsidiary-partner countries technology ratio & $\begin{array}{c}0.145^{*} \\
(1.87)\end{array}$ & $\begin{array}{c}1.156^{*} \\
(1.87)\end{array}$ & $\begin{array}{c}0.207 * * * \\
(3.00)\end{array}$ & $\begin{array}{c}1.230 * * * \\
(3.00)\end{array}$ & $\begin{array}{c}0.260 * * \\
(2.35)\end{array}$ & $\begin{array}{c}1.297 * * \\
(2.35)\end{array}$ \\
\hline Portfolio size & $\begin{array}{c}-0.309 * * \\
(-2.57)\end{array}$ & $\begin{array}{c}0.734 * * \\
(-2.57)\end{array}$ & $\begin{array}{c}-0.320 * * * \\
(-2.59)\end{array}$ & $\begin{array}{c}0.726 * * * \\
(-2.59)\end{array}$ & $\begin{array}{c}-0.274 * * \\
(-2.19)\end{array}$ & $\begin{array}{c}0.761 * * \\
(-2.19)\end{array}$ \\
\hline Acquisition entry mode & $\begin{array}{c}5.036 * * * \\
(4.61)\end{array}$ & $\begin{array}{c}153.855^{* * *} \\
(4.61)\end{array}$ & $\begin{array}{c}5.263 * * * \\
(4.44)\end{array}$ & $\begin{array}{c}193.014 * * * \\
\quad(4.44)\end{array}$ & $\begin{array}{c}5.159 * * * \\
-3.5\end{array}$ & $\begin{array}{c}173.975^{* * * *} \\
(3.50)\end{array}$ \\
\hline Institutional quality & $\begin{array}{l}-3.035 \\
(-1.25)\end{array}$ & $\begin{array}{c}0.048 \\
(-1.25)\end{array}$ & $\begin{array}{c}-4.317 * \\
(-1.74)\end{array}$ & $\begin{array}{l}0.013^{*} \\
(-1.74)\end{array}$ & $\begin{array}{l}-2.291 \\
(-0.75)\end{array}$ & $\begin{array}{c}0.101 \\
(-0.75)\end{array}$ \\
\hline Independent partner & $\begin{array}{c}-0.763 * * * \\
(-3.44)\end{array}$ & $\begin{array}{c}0.466 * * * \\
(-3.44)\end{array}$ & $\begin{array}{c}-0.700 * * * \\
(-3.26)\end{array}$ & $\begin{array}{c}0.496 * * * \\
(-3.26)\end{array}$ & $\begin{array}{c}-0.640 * * * \\
(-3.08)\end{array}$ & $\begin{array}{c}0.527 * * * \\
(-3.08)\end{array}$ \\
\hline Explorative alliances $* \mathrm{CD}$ subsidiary-partner & & & $\begin{array}{c}0.553 * * * \\
(3.13)\end{array}$ & $\begin{array}{c}1.739 * * * \\
(3.13)\end{array}$ & & \\
\hline Explorative alliances $* \mathrm{CD}$ parent-partner & & & & & $\begin{array}{c}1.275^{* * *} \\
(4.25)\end{array}$ & $\begin{array}{c}3.579 * * * \\
(4.25)\end{array}$ \\
\hline Constant & $\begin{array}{l}2.948 \\
(0.74)\end{array}$ & $\begin{array}{c}19.067 \\
(0.74)\end{array}$ & $\begin{array}{l}5.012 \\
(1.26)\end{array}$ & $\begin{array}{c}150.259 \\
(1.26)\end{array}$ & $\begin{array}{l}1.812 \\
(0.37)\end{array}$ & $\begin{array}{l}6.120 \\
(0.37)\end{array}$ \\
\hline Ln alpha constant & $\begin{array}{c}0.907 * * * \\
(6.75) \\
\end{array}$ & $\begin{array}{c}2.476 * * * \\
(6.75) \\
\end{array}$ & $\begin{array}{c}0.885^{* * *} \\
(6.34) \\
\end{array}$ & $\begin{array}{c}2.423 * * * \\
(6.34) \\
\end{array}$ & $\begin{array}{c}0.794 * * * \\
(4.97)\end{array}$ & $\begin{array}{c}2.213 * * * \\
(4.97) \\
\end{array}$ \\
\hline No. of observations & \multicolumn{2}{|c|}{161} & \multicolumn{2}{|c|}{161} & \multicolumn{2}{|c|}{161} \\
\hline Chi-squared & \multicolumn{2}{|c|}{$3392.424 * * *$} & \multicolumn{2}{|c|}{$25895.705^{* * *}$} & \multicolumn{2}{|c|}{$7262.625 * * *$} \\
\hline Log pseudo-likelihood & \multicolumn{2}{|c|}{-405.540} & \multicolumn{2}{|c|}{-404.470} & \multicolumn{2}{|c|}{-400.856} \\
\hline
\end{tabular}


Table 4: Results of the negative binomial models for Innovation quality

\begin{tabular}{|c|c|c|c|c|c|c|}
\hline \multirow{3}{*}{ Explanatory variables } & \multicolumn{6}{|c|}{ Innovation quality } \\
\hline & \multicolumn{2}{|c|}{ (1) } & \multicolumn{2}{|c|}{$(2)$} & \multicolumn{2}{|c|}{ (3) } \\
\hline & Coefficient & IRR & Coefficient & IRR & Coefficient & IRR \\
\hline CD subsidiary-partner & $\begin{array}{c}-0.409 * * * \\
(-3.01)\end{array}$ & $\begin{array}{c}0.664 * * * \\
(-3.01)\end{array}$ & $\begin{array}{c}-1.717 * * * \\
(-4.98)\end{array}$ & $\begin{array}{c}0.180 * * * \\
(-4.98)\end{array}$ & $\begin{array}{c}-0.476 * * * \\
(-3.10)\end{array}$ & $\begin{array}{c}0.621 * * * \\
(-3.10)\end{array}$ \\
\hline CD parent-partner & $\begin{array}{c}-0.310 * * \\
(-2.37)\end{array}$ & $\begin{array}{c}0.733^{* *} \\
(-2.37)\end{array}$ & $\begin{array}{c}-0.407 * * * \\
(-3.41)\end{array}$ & $\begin{array}{c}0.666^{* * * *} \\
(-3.41)\end{array}$ & $\begin{array}{c}-0.610 * * \\
(-2.56)\end{array}$ & $\begin{array}{c}0.543 * * \\
(-2.56)\end{array}$ \\
\hline Explorative alliances & $\begin{array}{c}0.673^{*} \\
(1.73)\end{array}$ & $\begin{array}{l}1.960^{*} \\
(1.73)\end{array}$ & $\begin{array}{l}-0.068 \\
(-0.15)\end{array}$ & $\begin{array}{c}0.934 \\
(-0.15)\end{array}$ & $\begin{array}{l}0.157 \\
(0.47)\end{array}$ & $\begin{array}{l}1.170 \\
(0.47)\end{array}$ \\
\hline Subsidiary size & $\begin{array}{l}-1.022 \\
(-1.16)\end{array}$ & $\begin{array}{c}0.360 \\
(-1.16)\end{array}$ & $\begin{array}{l}-1.454 \\
(-1.07)\end{array}$ & $\begin{array}{c}0.234 \\
(-1.07)\end{array}$ & $\begin{array}{l}-1.106 \\
(-1.18)\end{array}$ & $\begin{array}{c}0.331 \\
(-1.18)\end{array}$ \\
\hline Subsidiary age & $\begin{array}{l}0.024 \\
(0.73)\end{array}$ & $\begin{array}{l}1.024 \\
(0.73)\end{array}$ & $\begin{array}{l}0.023 \\
(0.59)\end{array}$ & $\begin{array}{l}1.024 \\
(0.59)\end{array}$ & $\begin{array}{l}0.026 \\
(0.76)\end{array}$ & $\begin{array}{l}1.026 \\
(0.76)\end{array}$ \\
\hline Subsidiary technological capital & $\begin{array}{c}0.724 * * * \\
(4.11)\end{array}$ & $\begin{array}{c}2.062 * * * \\
(4.11)\end{array}$ & $\begin{array}{c}0.795 * * * \\
(4.08)\end{array}$ & $\begin{array}{c}2.215^{* * *} \\
(4.08)\end{array}$ & $\begin{array}{c}0.694 * * * \\
(3.47)\end{array}$ & $\begin{array}{c}2.001 * * * \\
(3.47)\end{array}$ \\
\hline Subsidiary alliance experience & $\begin{array}{c}0.042 * \\
(1.83)\end{array}$ & $\begin{array}{c}1.043 * \\
(1.83)\end{array}$ & $\begin{array}{l}0.041 \\
(1.55)\end{array}$ & $\begin{array}{l}1.042 \\
(1.55)\end{array}$ & $\begin{array}{l}0.043 \\
(1.59)\end{array}$ & $\begin{array}{l}1.044 \\
(1.59)\end{array}$ \\
\hline Technological distance & $\begin{array}{c}-0.809 * * * \\
(-4.90)\end{array}$ & $\begin{array}{c}0.445 * * * \\
(-4.90)\end{array}$ & $\begin{array}{c}-0.827 * * * \\
(-4.70)\end{array}$ & $\begin{array}{c}0.437 * * * \\
(-4.70)\end{array}$ & $\begin{array}{c}-0.767 * * * \\
(-4.65)\end{array}$ & $\begin{array}{c}0.465 * * * \\
(-4.65)\end{array}$ \\
\hline Partners' technological capital & $\begin{array}{c}-0.241 * \\
(-1.89)\end{array}$ & $\begin{array}{l}0.786^{*} \\
(-1.89)\end{array}$ & $\begin{array}{l}-0.135 \\
(-1.00)\end{array}$ & $\begin{array}{c}0.874 \\
(-1.00)\end{array}$ & $\begin{array}{c}-0.214^{*} \\
(-1.72)\end{array}$ & $\begin{array}{l}0.807 * \\
(-1.72)\end{array}$ \\
\hline Subsidiary-partner countries technology ratio & $\begin{array}{c}0.284 * * * \\
(2.63)\end{array}$ & $\begin{array}{c}1.328 * * * \\
(2.63)\end{array}$ & $\begin{array}{c}0.424 * * * \\
(3.59)\end{array}$ & $\begin{array}{c}1.527 * * * \\
(3.59)\end{array}$ & $\begin{array}{c}0.279 * * \\
(2.36)\end{array}$ & $\begin{array}{c}1.322 * * \\
(2.36)\end{array}$ \\
\hline Portfolio size & $\begin{array}{l}-0.139 \\
(-0.96)\end{array}$ & $\begin{array}{c}0.870 \\
(-0.96)\end{array}$ & $\begin{array}{l}-0.163 \\
(-1.01)\end{array}$ & $\begin{array}{c}0.850 \\
(-1.01)\end{array}$ & $\begin{array}{l}-0.105 \\
(-0.66)\end{array}$ & $\begin{array}{c}0.900 \\
(-0.66)\end{array}$ \\
\hline Acquisition entry mode & $\begin{array}{c}3.894 * * * \\
(2.75)\end{array}$ & $\begin{array}{c}49.127 * * * \\
(2.75)\end{array}$ & $\begin{array}{c}4.746^{* * * *} \\
(3.32)\end{array}$ & $\begin{array}{c}115.146^{* * * *} \\
(3.32)\end{array}$ & $\begin{array}{c}3.607 * * \\
(2.29)\end{array}$ & $\begin{array}{c}36.843^{* *} \\
(2.29)\end{array}$ \\
\hline Institutional quality & $\begin{array}{l}-2.500 \\
(-0.81)\end{array}$ & $\begin{array}{c}0.082 \\
(-0.81)\end{array}$ & $\begin{array}{l}-5.142 \\
(-1.61)\end{array}$ & $\begin{array}{c}0.006 \\
(-1.61)\end{array}$ & $\begin{array}{l}-2.662 \\
(-0.82)\end{array}$ & $\begin{array}{c}0.070 \\
(-0.82)\end{array}$ \\
\hline Independent partner & $\begin{array}{c}-1.200 * * * \\
(-2.65)\end{array}$ & $\begin{array}{c}0.301 * * * \\
(-2.65)\end{array}$ & $\begin{array}{c}-1.079 * * \\
(-2.34)\end{array}$ & $\begin{array}{c}0.340 * * \\
(-2.34)\end{array}$ & $\begin{array}{c}-1.172 * * * \\
(-2.69)\end{array}$ & $\begin{array}{c}0.310 * * * \\
(-2.69)\end{array}$ \\
\hline Explorative alliances $* \mathrm{CD}$ subsidiary-partner & & & $\begin{array}{c}1.497 * * * \\
(4.68)\end{array}$ & $\begin{array}{c}4.468 * * * \\
(4.68)\end{array}$ & & \\
\hline Explorative alliances $* \mathrm{CD}$ parent-partner & & & & & $\begin{array}{c}0.643 * * \\
(2.46)\end{array}$ & $\begin{array}{c}1.903 * * \\
(2.46)\end{array}$ \\
\hline Constant & $\begin{array}{l}0.858 \\
(0.17)\end{array}$ & $\begin{array}{l}2.359 \\
(0.17)\end{array}$ & $\begin{array}{l}4.434 \\
(0.83)\end{array}$ & $\begin{array}{c}84.245 \\
(0.83)\end{array}$ & $\begin{array}{l}1.440 \\
(0.28)\end{array}$ & $\begin{array}{l}4.219 \\
(0.28)\end{array}$ \\
\hline Ln alpha constant & $\begin{array}{c}1.392 * * * \\
(7.03) \\
\end{array}$ & $\begin{array}{c}4.024 * * * \\
(7.03) \\
\end{array}$ & $\begin{array}{c}1.317 * * * \\
(6.74) \\
\end{array}$ & $\begin{array}{c}3.732 * * * \\
(6.74) \\
\end{array}$ & $\begin{array}{c}1.361 * * * \\
(6.68) \\
\end{array}$ & $\begin{array}{c}3.902 * * * \\
(6.68) \\
\end{array}$ \\
\hline No. of observations & \multicolumn{2}{|c|}{161} & \multicolumn{2}{|c|}{161} & \multicolumn{2}{|c|}{161} \\
\hline Chi-squared & \multicolumn{2}{|c|}{$2346.072 * * *$} & \multicolumn{2}{|c|}{$34451.419 * * *$} & \multicolumn{2}{|c|}{$9550.268 * * *$} \\
\hline Log pseudo-likelihood & \multicolumn{2}{|c|}{-419.558} & \multicolumn{2}{|c|}{-414.859} & \multicolumn{2}{|c|}{-418.574} \\
\hline
\end{tabular}




\section{FIGURES}

Figure 1: Effect of interaction between alliance type and cultural diversity (subsidiary-partner) on innovation quantity

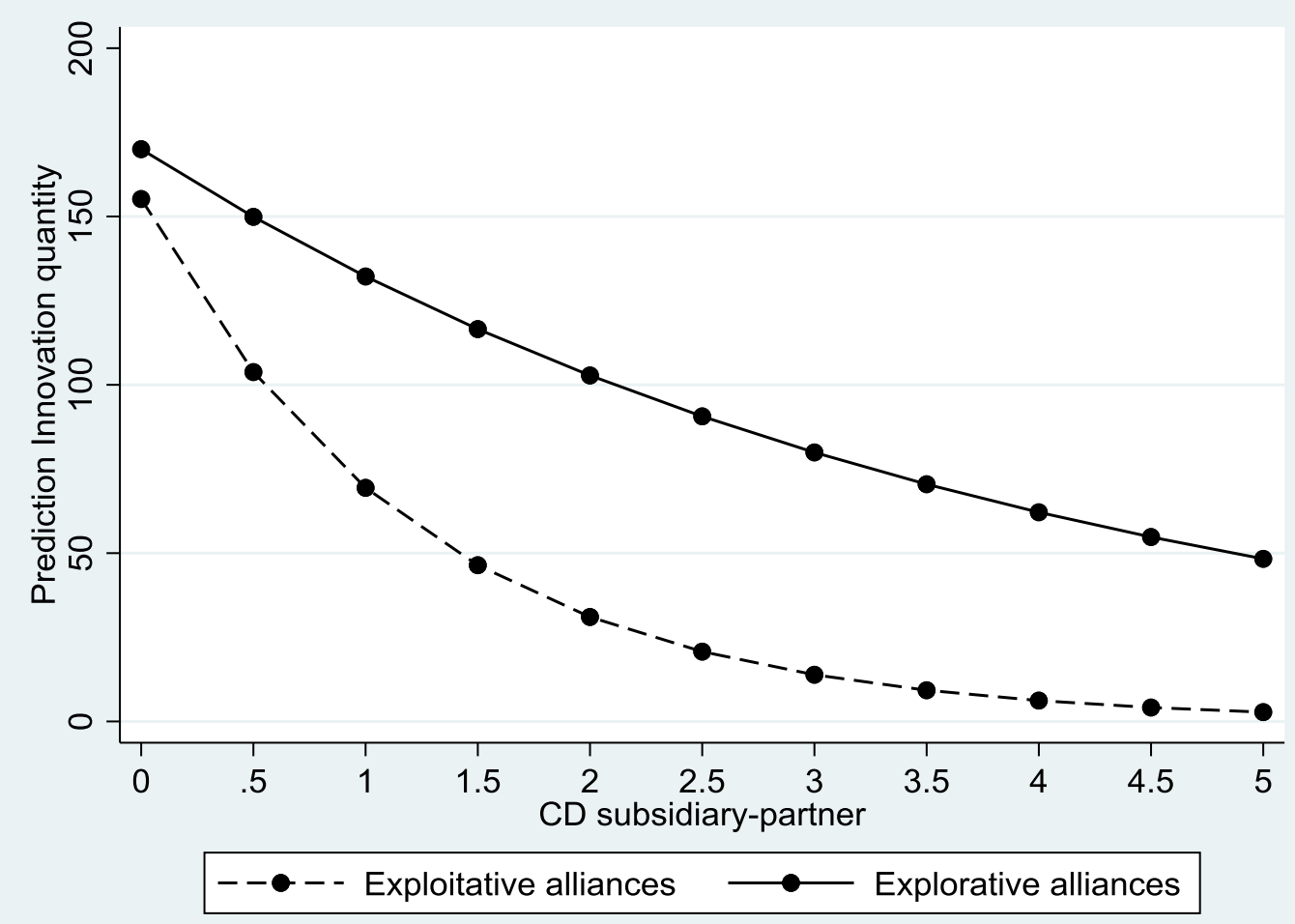

Figure 2: Effect of interaction between alliance type and cultural diversity (subsidiary-partner) on innovation quality

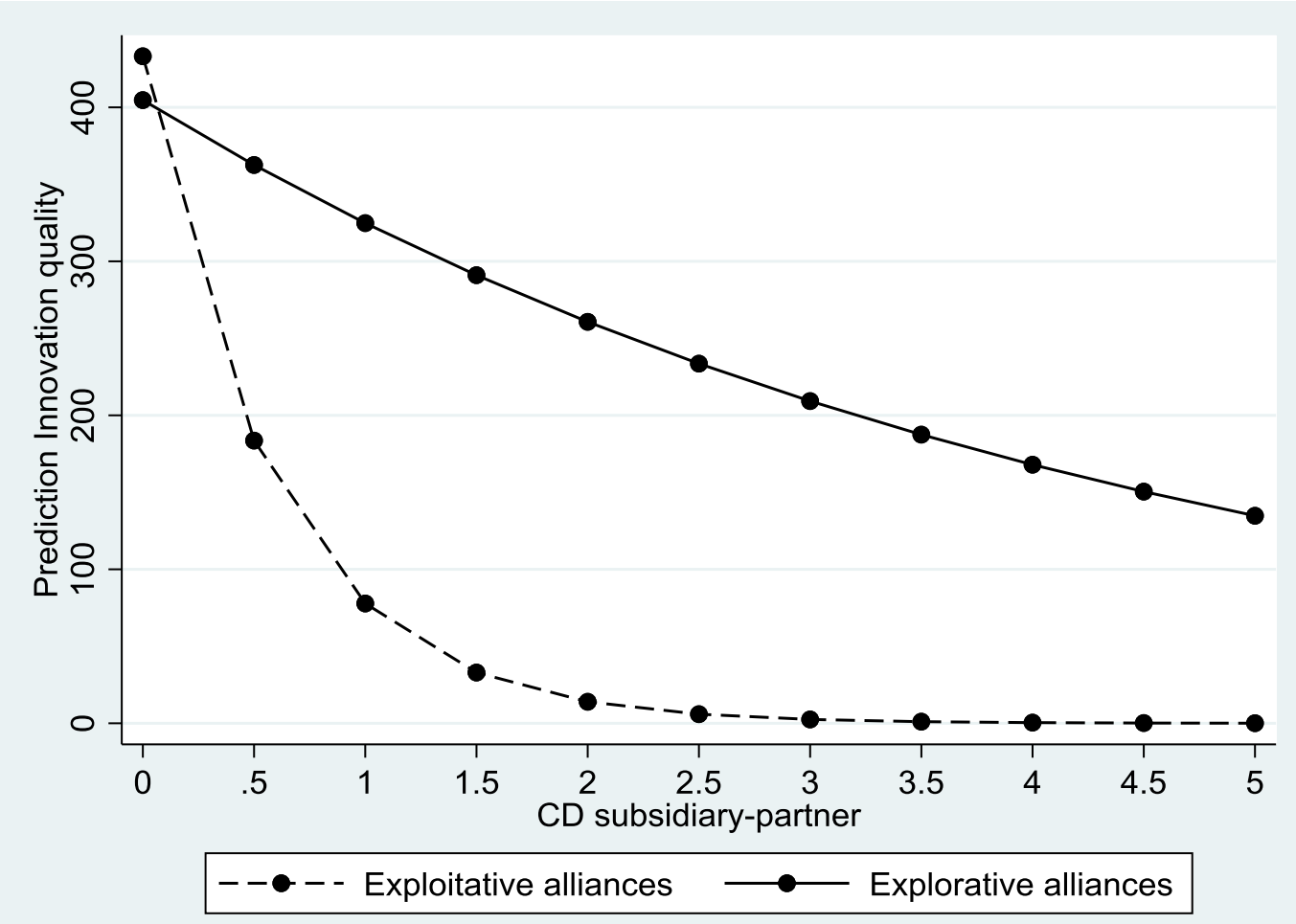


Figure 3: Effect of interaction between alliance type and cultural diversity (parent-partner) on innovation quantity

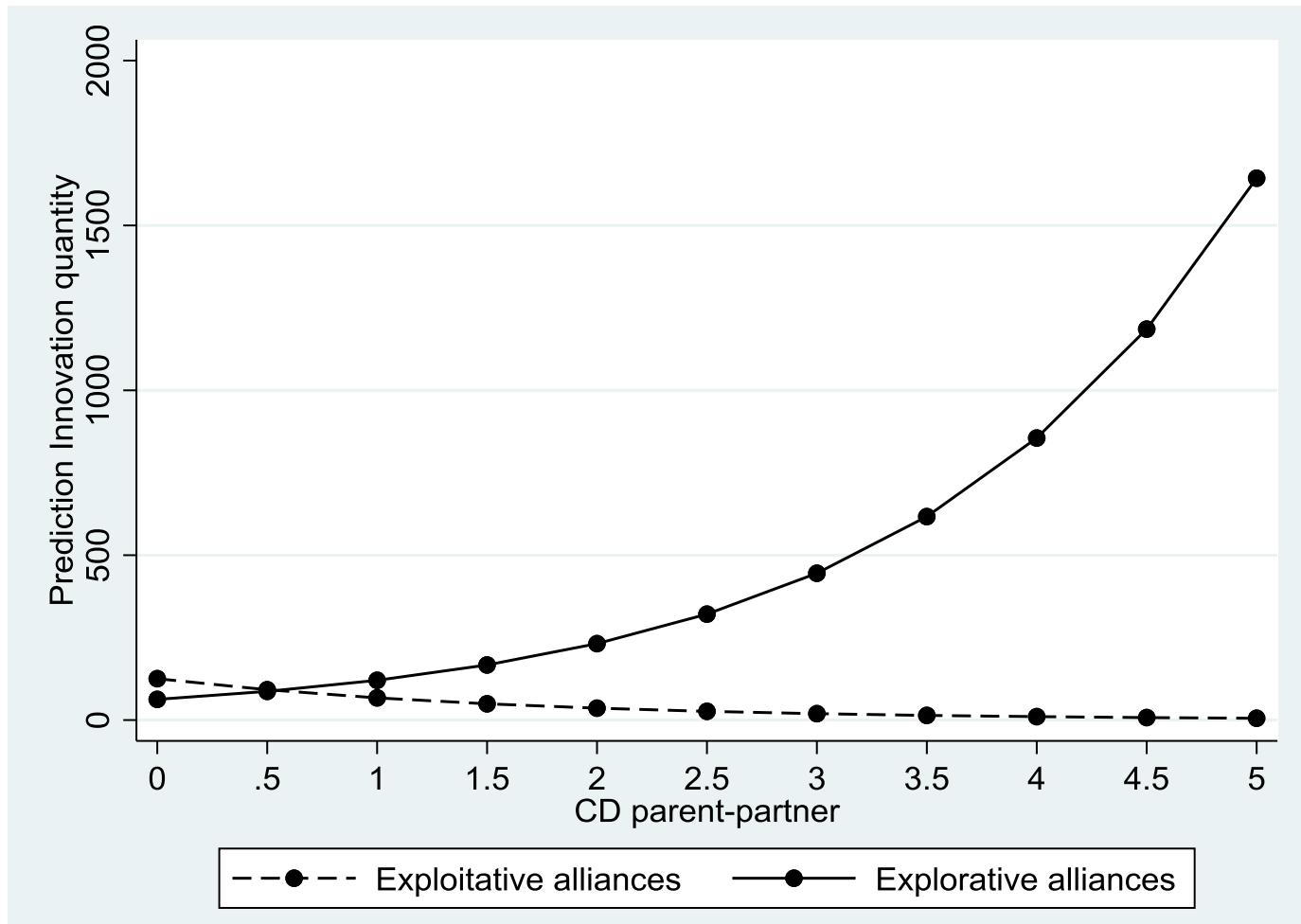

Figure 4: Effect of interaction between alliance type and cultural diversity (parent-partner) on innovation quality

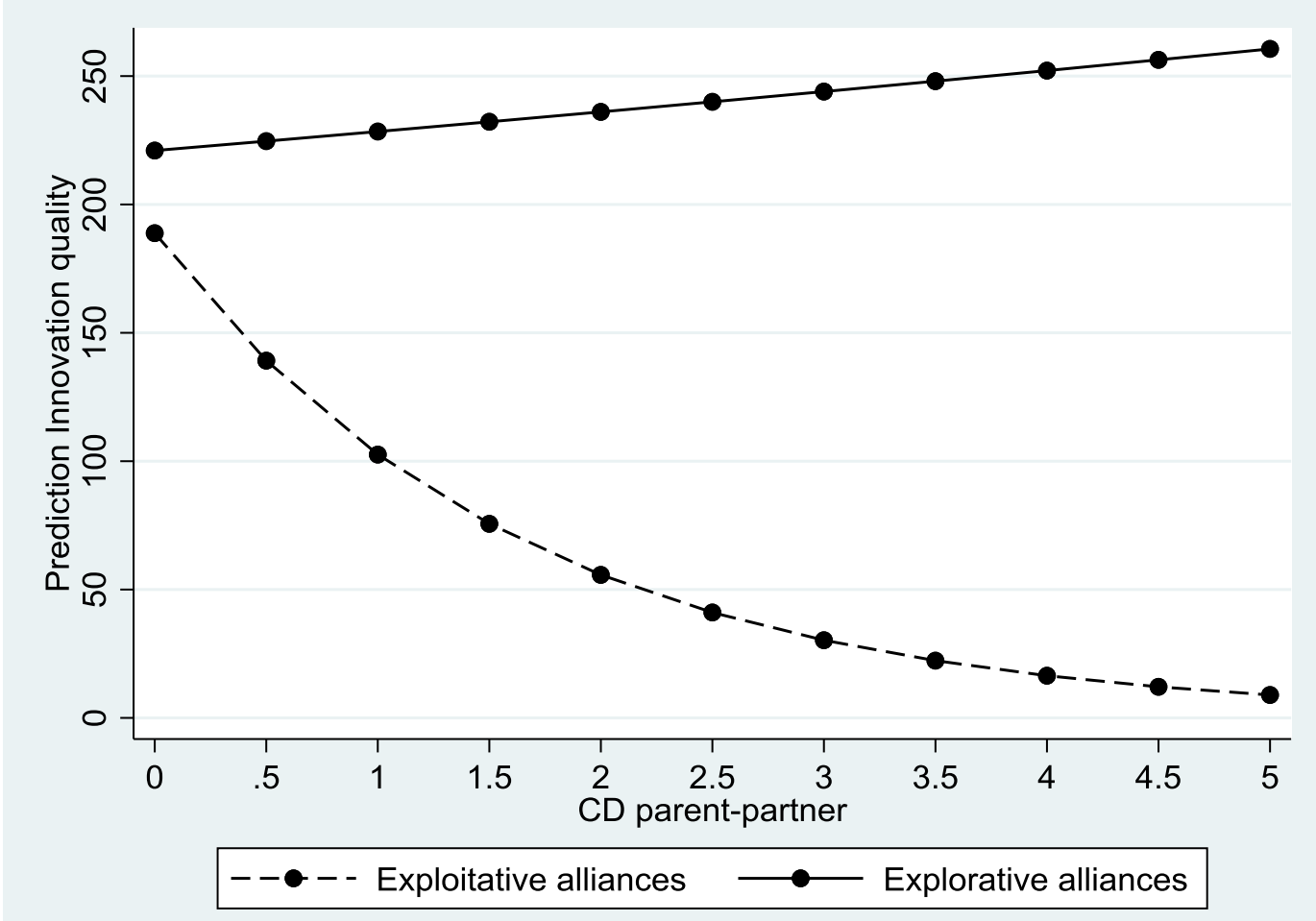

